\title{
Vulnerability of Ghanaian women cocoa farmers to climate change: A typology
}

\begin{abstract}
Climate change, increasingly recognized as a hurdle to achieving sustainable development goals, has already begun impacting the lives and livelihoods of people around the world, including on the African continent. Vulnerability is a concept often employed in the context of climate change to identify risks and develop policy and adaptation measures that address current and projected impacts. However, it is situated in a broader social context, driven by factors such as land tenure and access, livelihood diversification, and empowerment, which single out historically marginalized groups like women. This paper applies a vulnerability framework to a case study of cocoa farming in the Central Region of Ghana, depicting not only the variety of factors contributing to climate change vulnerability, but also different narratives on vulnerability that emerge based on a woman's relation to cocoa production itself. The paper conveys how homogeneous representations of women farmers and the technical focus of climate-orientated policy interventions may threaten to further marginalize the most vulnerable and exacerbate existing inequalities. This has implications for both climate change policy design and implementation, as well as the broader social development agenda that has bearing on vulnerability.
\end{abstract}

Keywords: gender, vulnerability, Africa, agriculture, climate change

\section{Introduction}

Climate change is increasingly recognized as a hurdle to achieving sustainable development goals in developing countries and emerging economies. The effects on temperature and rainfall patterns are already visible and will continue to present challenges into the future, especially in rural and agricultural settings (IPCC, 2014). While climate change is not often acknowledged as the primary influence on people’s decision-making, current international pressures necessitate considering climate change as a prominent risk factor. Furthermore, within 
the continued support for climate change and development projects, it is important to account for the needs of a heterogeneous population, else relevant policies and programmes may serve to entrench inequalities rather than protect the most vulnerable.

Vulnerability is a concept often employed in the context of climate change to identify risks and develop policy and adaptation measures that address current and projected impacts, while also offering an opportunity to introduce social factors in a way that engages with the climate discipline. Understanding what underlies this vulnerability is crucial to developing successful adaptation strategies and preparing for uncertainty. Women have historically been singled out as a 'vulnerable' population, but also heralded as contributors to sustainable development through their roles on farms, in households, and furthering economic and social growth (Beuchelt \& Badstue, 2013; Boserup, 1970; Carr, 2008b). These arguments have stimulated the inclusion of gender considerations in the climate and development literatures; however, current scholarship argues that treatment of women as a homogeneous group and difficulties integrating biophysical and social components of vulnerability persists in development research and practice (Arora-Jonsson, 2011; Carr \& Thompson, 2014; Rodenberg, 2009; Tschakert \& Machado, 2012). This paper aims to address these shortcomings by applying a novel typology to respond to the question: How does vulnerability vary among women within cocoa farming communities?

The paper explores a case study of the cocoa farming sector in Ghana to illustrate ways of thinking about climate change and adaptation within a vulnerability framework, and how this might provide insights for the broader context of West African development and beyond under a changing climate. It is organised as follows: a brief overview of key themes in the gender and development literature relevant to climate change vulnerability lays the foreground. The paper 
then elaborates a vulnerability framework through which to examine the case study and women's engagement in farming in the context of climate change. Finally, the study synthesizes the divergences among women farmers, before reflecting on the policy relevance and future research directions.

\section{Gender, Development, and Climate Change}

\subsection{Gender and development scholarship - setting the scene}

While gender is one factor within the vulnerability discourse, climate change is a relative newcomer to the broader discussions on gender and development, a field with decades of research and practice. Gender analysis within development studies originally responded to a recognition that benefits from economic projects were not accruing (or "trickling" down) to the poor and women (Lambrou, 2001). The subsequent gender research has deepened understanding of how development processes affect men and women differently, yet has also experienced its own set of debates and critiques reviewed briefly below.

One of the critical debates concerns the distinction between 'women in development' and 'gender and development' (GAD) research. Whereas the former focused primarily on the participation of women in development processes, the latter called for greater attention to gender equity in development policy and practice - including challenging established gender roles and relations, eliminating institutionalized forms of discrimination, and ensuring equal rights (Bradshaw \& Linneker, 2014; Schipper \& Langston, 2014). The common argument between these camps is that economic development has different impacts on men and women and their experiences of poverty (Momsen, 2010), yet the lessons stemming from GAD - especially 
regarding the need for finer resolution in gender analyses - are particularly relevant for studies related to climate change vulnerability.

The gender literature has also flirted with various framings of women within the development context, particularly in relation to interactions with the environment and sustainability. Two disparate and monochromatic framings of women's relationship with the environment - one as victim and one as caretaker - have characterised the field and only recently benefited from context-specific appraisal (Arora-Jonsson, 2011; Bob \& Babugura, 2014; MacGregor, 2010; Rodenberg, 2009). With roots in the discussion of entitlements ${ }^{1}$, women are traditionally viewed as a marginalized demographic - poorer, malnourished, with limited access and power (Denton, 2002; FAO, 2011; Namubiru-Mwaura, 2014; Okali \& Naess, 2013). The natural disasters literature features prominently in relation to gender and vulnerability, pointing to women’s greater exposure to and impacts from hazards (Cannon, 2002; Ravera, et al., 2016; Reyes, 2002; Tschakert \& Machado, 2012). The other image of women - as virtuous, caretakers of the environment, closer to nature, more knowledgeable about natural resources, and most at risk from environmental degradation - was perpetuated through the Women, Environment, and Development (WED) discourse (Schipper \& Langston, 2014).

Both images have received criticism as too simplistic or idealised (Arora-Jonsson, 2011; Bob \& Babugura, 2014; Cornwall, 2005; Meinzen-Dick, et al., 2014; Okali \& Naess, 2013), and there have been subsequent counter-examples and critiques of the "feminisation of vulnerability" (Djoudi, et al., 2016; Nelson, et al., 2002). Although lower incomes and limited access to resources are generally acknowledged to impede coping with stresses, they are not restricted by gender-specific traits or knowledge (Bradshaw \& Linneker, 2014; Chaudhury, et al., 2012; Masika, 2002). 


\subsection{Gender and climate change vulnerability - a review and framework}

This progression in constructing gender is critical to note, because of how heavily the discourse on gender and development relies on a set of risks and vulnerabilities, providing a link with current climate change discussions. Discussion of how climate change yields gendered impacts surfaced around 15 years ago (Dankelman, 2002; Masika, 2002), and is an active and growing area of research (Alston, 2014; Arora-Jonsson, 2011; Huyer, 2016; Nelson, et al., 2002; Ravera, et al., 2016; Terry, 2009).

One current critique within vulnerability discourse is that attempts to integrate the biophysical and socio-economic factors in vulnerability are underrepresented in the climate change and agriculture research and policy agenda (Kakota, et al., 2011; Schipper \& Langston, 2014), and that includes failing to adequately recognise institutional elements, entitlements, and ‘agency’ (Preston, et al., 2011). While gender has long been considered a social issue in development studies literature - intertwined with land access and tenure, divisions of labour and income, and empowerment (Boserup, 1970; Jackson, 2002; Momsen, 2010; Moser, 2007) much of the early research on climate change and gender weighs heavily on biophysical processes and consequent impacts (Bradshaw \& Linneker, 2014; Huyer, 2016; Lambrou \& Piana, 2006; MacGregor, 2010). Climate change, however, is increasingly acknowledged as an exacerbating factor in existing social inequities (Demetriades \& Esplen, 2008; Olsson, et al., 2014; Ribot, 2010), and one among many livelihood concerns and constraints contributing to the vulnerability of smallholder farmers (Mertz, et al., 2009; Nyantakyi-frimpong \& Bezner-kerr, 2015; Perez, et al., 2015). This supports the argument for expanding the scope of climate and gender studies to a greater range of socio-economic factors. 
How research is framed also has implications for constructing solutions and designing policy. For climate change and agriculture, solutions have focused largely on technical responses to extreme events and novel conditions (e.g. Berry, et al., 2006; Challinor, et al., 2007; Coe \& Stern, 2011; Schipper \& Langston, 2014). These critiques of focusing on the technicalities of adaptation and mitigation without adequate attention to social dynamics, drivers, and participation, are applicable in the policy realm (Boyd, 2002; Nelson, et al., 2002; Reyes, 2002; Skinner, 2011). There is concern that such trends in framing could undermine efforts to understand and address the gender dynamics unpinning vulnerability, particularly for the most marginalized (Carr, 2008b; Jost, et al., 2016; Wong, 2009).

Gendered climate change studies can also glean lessons from the debates gender and development research has engaged in over the decades. For example, studies on climate and gender often hone in on the differences between men and women, yet devote less attention and investigation to the heterogeneity of impacts and responses (Boyd, 2002; Djoudi, et al., 2016; MacGregor, 2010; Perez, et al., 2015; Thompson-Hall, et al., 2016). This is not to say that research has blindly embraced the assumption that men and women are homogenous and united groups (see Arora-Jonsson, 2011; Carr 2008b; Cornwall, 2005), but the image has dominated the climate change literature thus far.

In terms of solutions and interventions, the gender literature provides a history of work on empowerment - including topics of educational attainment; access, control, and agency ${ }^{2}$ over resources, incomes, and decision-making; and perceived influence over the future (Carr \& Thompson, 2014; Resurrección, 2013; Seebens, 2010). In agricultural systems, placing power in women's hands is accepted as means to imbue confidence and a sense of ownership necessary to manage land and income well. Women's empowerment and fulfilment of leadership roles are 
being postured as important for a more climate resilient future (Bob \& Babugura, 2014).

Researchers are also articulating the connections between self-efficacy, decision-making powers, perceptions, and the extent to which people can manage climate shocks and change (Adger, et al., 2009; Brown \& Westaway, 2011).

Review studies have shown that only a small portion of climate vulnerability assessments focus on social vulnerability, examine societal roots of vulnerability, or discuss risk as both a social and biophysical phenomenon (Preston, et al., 2011; Wise, et al., 2014). At the same time, examining gender from a vulnerability perspective allows for greater accessibility within climate change discussions. This paper aims to address the gap between social and biophysical vulnerability by adopting an analytical framework that builds on the definition of vulnerability as "the propensity or predisposition to be adversely affected by climate change or other hazardous non-climatic events” (Oppenheimer, et al., 2014, p.1050). This definition is consistently partnered with three related conceptual elements: the exposure of a system to one or multiple stresses; a measure of how sensitive it is to the impacts; and its capacity to respond and adapt (Adger, 2006; Eakin \& Luers, 2006; Füssel, 2007). These elements, examined below, can go beyond biophysical constraints typically found in modelling vulnerability of natural and agricultural systems.

\section{Exposure}

Exposure generally refers to the degree, duration, and/or extent of impact, in this case including climate variables, projected changes, and impacts on the cocoa farming system. At the level of individual farmers, perceptions provide a necessary bridge between the scientific understanding of climate change and the impacts as felt on the local and farm levels (Simelton, et 
al., 2013; Westerhoff \& Smit, 2009). These experiences reflect the different needs and optimal growing conditions of various crops and farming arrangements, as well as rights over the land.

\section{Sensitivity}

Sensitivity addresses factors that could influence the level of climate-related impacts, such as access to land and income diversification. Livelihood diversification is a key source of differentiation in terms of sensitivity to climate change, as different types and combinations of livelihood sources affect the extent to which climate change impacts are felt. However, not merely the number of accessible income generating activities, but also the types of activity influence sensitivity. For instance, a focus simply on crops (even a diverse mix) might be more sensitive to climate-related shocks than trading goods at a local market. In this sense, livelihood diversification bridges biophysical and social sides of climate change vulnerability, integrating tolerances of specific income sources to bioclimatic variables with capacity to diversify livelihood strategies (McOmber, et al., 2013; Twomlow, et al., 2008).

\section{Adaptive Capacity}

Adaptive capacity is the ability to respond to shocks, and in this analysis was largely considered a product of empowerment, which integrates access, agency, and perceptions (Brown \& Westaway, 2011). Researchers argue that perceptions and cognitive constructs of risks and adaptation options also have a bearing on this ability to adapt (Adger, et al., 2009). Brown and Westaway (2011) suggest that adaptive capacity in fact depends on factors like sense of selfefficacy, optimism, decision-making, and perceptions, in addition to the modes and extent to which people will be able to manage climate shocks, stresses, and change. In their earlier work, 
Emirbayer and Mische (1998) describe agency as an ability to conceptualize alternate futures and to reflect on past and present circumstances and future manoeuvrability.

The remainder of this paper engages with the empirical case of women farmers in Ghana's cocoa sector to further discussions on gender, development, and climate change vulnerability. The next section describes the empirical case study methods, including the development of a typology, which coupled with the vulnerability framework enables the study to glean insights into the differentiated vulnerability of women farmers and the potential for policyrelevant distinctions in vulnerability to inform potential responses to climate change.

\section{Case study area and methods}

\subsection{Cocoa farming in Ghana}

Recently, cocoa farming in West Africa has received considerable attention in relation to the challenges from climate change and the growing region's continued suitability. In Ghana, cocoa is a critical component of both national and local economies, representing 3.4\% of GDP and supporting 800,000 mainly smallholder farmers (MESTI, 2013). It is also considered to be susceptible to shifts in temperature and precipitation due to climate change, with the climatic suitability of most, but not all, current and potential growing regions decreasing (Antwi-Agyei, et al., 2012; Läderach, et al., 2013; Schroth, et al., 2016a). Based on biophysical considerations, those reliant on cocoa may be particularly sensitive to climate change simply because cocoa itself is sensitive to climatic conditions and is grown over long time periods, limiting the opportunity for agronomic adaptations such as changing crops or varieties. 
While this case study is situated in a zone currently projected to remain suitable for growing cocoa but require coping strategies (Bunn, et al. 2016; Schröth, et al. 2016b) - and thus presents a conservative analysis of the potential level of vulnerability - many of the themes will be relevant to more extreme cases necessitating transformation and adjustment. Furthermore, focusing on the exposure of single crops to climate change draws the focus of analyses to the biophysical component of vulnerability and risks overlooking the underlying factors affecting sensitivity and adaptive capacity. As such, the land tenure, livelihoods portfolios, and empowerment that also play a prominent role in vulnerability are explored further in this analysis.

\subsection{Case study site and methods}

The case study, located in the Assin South District around the northern and eastern perimeter of Kakum National Park in the Central Region of Ghana, consisted of six cocoaproducing communities. As is typical, these communities are composed primarily of smallholder farmers who grow food crops such as maize, cassava, plantain, cocoyam and vegetables either alongside cocoa, or intercropped with seedlings to provide shade during the establishment and rehabilitation of cocoa farms (Duguma, et al. 2001; Hill, 1963, p.188). While there are no strictly defined gender patterns associated with particular crops in Ghana - there are instances of men and women growing crops for both subsistence and sale - a general pattern (identified by Doss, 2002) is reflected in the study area where men are more likely to grow and manage cash crops intended for sale.

The communities were all originally established two or three generations ago (between 60-75 years), and so represent the established nature of cocoa communities in the region, 
increasingly typical as forest clearance for new farms becomes more difficult. Despite relatively limited spatial representativeness, the ethnic composition, tenure systems, and social dynamics varied within and between villages. This heterogeneity facilitated analysis by capturing critical dimensions of factors of vulnerability.

Qualitative case study methods used in this study are well suited to addressing 'how' and 'why' questions, investigating the dynamic social norms and sensitive issues confronted here (such as tenure, access to resources, intra-household dynamics), and where building trust with respondents is key (Yin, 2003). Research participants were purposively selected, using referrals from interviewees whenever possible. In total, 102 semi-structured interviews (49 males, 53 females) and 12 focus groups (6 male and 6 female) were conducted in Twi with the assistance of a translator between June and August 2014.

To examine vulnerability among women cocoa farmers, a typology is used for the following analysis. This typology of women cocoa farmers (similar to the use of groups in Carr, 2008a) emerged from initial interviews with community leaders and formed the backbone of purposive sampling designed to capture the diversity of women in the communities.

\subsection{Typology of women cocoa farmers}

The typology is supported by the existing literature highlighting the centrality of land tenure, rights, and inheritance. In Ghana, only $20 \%$ of cocoa farm operators or managers are women, their land holdings are on average half the size of men's, and they are commonly still expected to work on husbands' farms (Vigneri \& Holmes, 2009). Furthermore, men generally still control the monetary gains from cash crops like cocoa (Barrientos, 2013), although women 
do leverage their labour contributions in directing cash expenditure in households, for example on children's education (Duncan, 2010).

Gender norms are both the outcome of negotiations within households and culturally embedded normative perceptions regarding gender roles and rights (Lambrecht, 2016). Customary norms associated with women's access to cocoa land illustrate this point, having historically been intimately wrapped with the dynamics of obligation and reciprocity in conjugal relations and their labour contribution on farms (Amanor, 2010; Berry, 2009; Quisumbing et al., 2001). After the abolition of slavery and formal prohibition of pawning (debt slavery) at the beginning of the 20th century, wives' labour became essential for the establishment of cocoa farms (Allman, 1996), yet wives and children are increasingly claiming that unpaid labour entitles them to part ownership, or ownership of part of the trees they establish. This 'sweat equity' is a critical mode of land acquisition for women (Quisumbing et al., 2001), and has been formally recognized in the Intestate Succession Law (PNDCL 111). It is generally interpreted as specifying one-third each of the farm and other assets for the spouse, children, and maternal family should a husband die intestate (Kutsoati \& Morck, 2014; Quisumbing et al., 2001). In practice, the law is not widely adhered to, although it has been associated with a shift in customary practices (Evans et al., 2015).

Women have increasingly accessed land through gifts given to them by husbands or fathers in recognition of their contribution to the farm, a practice particularly common among the matrilineal Akan (Duncan, 2010; Kasanga \& Kotey, 2001; Quisumbing et al., 2001). For instance, one interview respondent revealed that although conventionally in her patrilineal ethnic group (Krobo) land was conventionally passed to males, her "father was kind and gave land to all his children”. Furthermore, female focus group discussants noted that although males still 
dominate access to cocoa land, customary arrangements were, in their view, leading to more equality: "Previously women were not allowed to inherit any form of property. Currently being male or female you can inherit family properties, but men inherit the chieftaincy stool ${ }^{3}$ and females also inherit the queen's stool.” These examples demonstrate the ongoing processes of negotiation and navigation between individuals, groups, and collective norms that render customary institutions at least partially fluid (Amanor \& Ubink, 2008; Berry, 1993).

Embedding this historical legacy and enduring traditions ensures that divergences, not only between men and women but also amongst women in the same community, are captured in the examination of vulnerability. Under the typology, a woman was considered a 'Direct Cocoa Farmer' (29/53 interviewees) if she operated her own cocoa land that was inherited, purchased, or sharecropped, although she might have also participated in cocoa farming activities (e.g. harvesting or weeding) on a spouse’s farm. Conversely, an 'Indirect Cocoa Farmer' (22/53 interviewees) did not operate her own cocoa farm but primarily was engaged in cocoa as a labourer on a spouse's land in addition to growing food crops, either on a spouse's land or her own land. Two unmarried women had no access to a cocoa farm, and were thus considered 'NonCocoa Farmers', but not included in the analysis due to small sample size. This typology was simplified from one using the mode of land acquisition as a means of further delineation.

In practice, there is a huge variation in arrangements over land, which is simplified in the direct-indirect distinction. However, this typology represents a fundamental difference that best suits balancing development of theoretical understandings and policy-relevant generalizations, while still capturing the within group heterogeneity emphasized in much of the gender and development literature (Arora-Jonsson, 2011; Carr, 2008b; Cornwall, 2005). These designations 
were employed to interrogate depictions of climate vulnerability and gender with respect to exposure, sensitivity, and adaptive capacity. The results are discussed in relation to these themes.

\section{Results: Vulnerability among Women Cocoa Farmers}

The next sections explore the distinct experiences of direct and indirect female cocoa farmers, employing the vulnerability framework presented earlier to assess each individually, followed by a discussion drawing together trends from the two.

\subsection{Direct Cocoa Farmers}

Exposure

Farmers honed in on the quantity and timing of rainfall as a key indicator of exposure. Direct cocoa farmers focused on difficulties stemming from extended periods without rainfall and also framed issues of precipitation in relation to the amount and intensity of 'sunshine'. These perceptions align more closely with those traditionally thought of as men's. For example, in a study by Thomas, et al. (2007), male South African smallholder farmers saw drought as a risk more often than women, a result the authors attributed to differential livelihood strategies. In this case, where some women control the historically male-dominated "cash crops", they faced the same exposure to climatic variables and had similar perceptions of that exposure.

Direct cocoa farmers might also incur additional expenses of time and effort due to climate changes (e.g. turning cocoa beans during heavy rains; extra weeding; replanting after seedlings die; carrying cocoa harvests over flooded roads), not felt by indirect cocoa farmers. One woman articulated how during heavy rains “cars can’t make it through on the road. Beans will be heaped and ready to get picked up but no truck will come. Then I will have to hire labour 
to carry bags.” Although these additional costs from labour and inputs are a constraint on women operating their own cocoa farms, it is also important to note these impacts are less directly harmful to basic subsistence.

A focus on longer-term trends by direct cocoa farmers reflects relatively greater permanence of cocoa ${ }^{4}$ compared with annual food crops. These farmers considered how conditions had changed over the course of their lives or since their parents' time. As one farmer illustratively stated, “rainfall was much more reliable when I first started; now it’s harder to predict.” Variables that farmers with cocoa can actually control are relegated to enduring actions like planting shade trees, for which long-term trends and not just extreme events hold relevance.

\section{Sensitivity}

The sensitivity component of vulnerability more clearly demonstrates the role of nonbiophysical factors. 'Diversification' was recognized as a common means by which to spread risk and manage shocks. Particularly among direct cocoa farmers, oil palm was frequently cited as an additional reliable cash crop, albeit less lucrative than cocoa, which formed an essential part of many women's livelihood portfolios and served to fill gaps in cocoa income streams throughout the year. The preparation of food and other off-farm income also presented more consistent and dependable sources of revenue, less at the mercy of adverse weather conditions. Therefore, those with off-farm income sources could find themselves in a more secure position and more able to endure hardships.

While women noted that money from cocoa is often already committed - to school fees, health services, and reinvestment into the farm - it provides a certain amount of initial stability and capital at hand that underpins the ability to adopt diverse pursuits (e.g. Davis, et al. 2014). 
Women farmers recognised the virtuous cycles that can emerge as a result of diversifying household income. Capital from cocoa farming was frequently cited as the enabling force in this livelihood diversification, necessary to cover start-up costs and purchase products to sell at markets. One 'chop-bar' owner noted that the income from selling the popular rice and bean dish, watkye, has allowed her to make additional investments, including acquiring new land, putting children in good schools, and setting aside money for savings. Her response illustrates how financial resources are critical to undertaking income generating activities that spread risk, and it emphasises the positive feedback loop often catalysed by initial cocoa finance. Responses from direct cocoa farmers demonstrated how they used their income from cocoa to diversify into other pursuits, and highlighted how the inability to access or control cash crop management and income may preclude others from reaching these more secure positions.

\section{Adaptive Capacity}

As noted earlier in the paper, empowerment is well-aligned with what's seen as building adaptive capacity, including both tangible means to make decisions and the perceived ability. The freedom income from cocoa provides - with respect to decision-making powers, ability to diversify income, and the capacity to educate children - can be an empowering force (Siulemba \& Moodley, 2014). Many of the direct cocoa farmers enjoyed complete autonomy over their farms, and some even expressed the desire to keep land separate from their husbands' to avoid the 'politics of land inheritance' (especially with their husbands' extended families), have assurance over providing for their families (particularly where polygamy is still practiced), and safeguard their children's inheritances. Others noted that husbands and wives can work on each other's farms and make decisions jointly. Joint management was portrayed as a choice, and often framed as a measure to mitigate risks from weather and markets, using the variation in land 
character to yield a good harvest on at least one plot in any given year. It also may be a useful tool where feasible to respond to increased variability of weather anticipated under climate change scenarios.

Purposefulness and future orientation emerged through the interviews with direct cocoa farmers, as important considerations in the actions and wellbeing of the farmers. These were manifest as aspirations for children and to some extent other plans for the future, such as business development in urban areas or building improvements. Many implied or said outright that they continued to put great effort into farming so as to earn enough for their children to become well educated and 'achieve a better station in life'. These women often implicated the image of a 'hardworking woman' as a means of achieving these goals. The description one direct cocoa farmer provided was typical: "Those who succeed are the ones who put in great effort and much time and energy, while those who are lazy or don't make an effort will complain of low yields and no support”. This reflects the mentality that taking control of the present could lead to future outcomes they desired and illustrates how perceptions of self-efficacy serves as a mark of agency and empowerment (Brown \& Westaway, 2011).

\subsection{Indirect Cocoa Farmers}

\section{Exposure}

In general, indirect cocoa farmers highlighted the short-term rainfall patterns they and their crops were exposed to. Rainfall dictates when to plant and harvest in each year, and whether crops succeed or fail. In the specific year of the study, the rainy season had started late and been heavy. Many women described cassava rotting in their fields due to excessive rainfall in conjunction with poor drainage; harvests may have come late or not at all. One farmer 
illustrated this point, noting “This year it did not rain on time. I should have harvested maize already, but rains didn’t come.”

As indirect cocoa farmers explained, "if you are producing tomatoes and pepper, which are not doing well, it is possible to switch to garden eggs and okra and it will be wonderful...” or “...If the cocoa does poorly, and the food crops do well, they can serve to supplement for inadequate cocoa harvest. One doing well does not dictate the other's success”. While these actions demonstrate differential exposure of crops, switching between crops is often deemed a short-term coping measure, which may not suffice as climate stressors more regularly threaten the success of agricultural production or novel conditions are experienced.

\section{Sensitivity}

As mentioned for direct cocoa farmers, livelihood diversification was often a strategy respondents claimed reduced their sensitivity; yet indirect cocoa farmers generally equated this to crop diversification. Although petty trading was also mentioned, it was usually deemed less important. The income streams women controlled were generally perceived as a stopgap, their importance downplayed compared to that of cocoa. Selling food crops was a useful source of income for their “upkeep”, making household ends meet, and smoothing out the periods between cocoa harvests.

Several women touched upon the challenges associated with a reliance on food crops, alluding to periods where the market may be flooded with certain produce (e.g. maize or tomatoes) and prices would be consequently depressed; there is only a limited amount of flexibility and room for mitigating such unforeseen circumstances. However, the option to 
reduce sensitivity to climate-related incidents is not always possible. As one direct cocoa farmer explained, “[Many women] don’t sell, because they don’t have money to start a business.”

\section{Adaptive Capacity}

The decision-making liberties afforded indirect cocoa farmers varied dramatically, from jointly managing land to having little or no input in any decisions. Women whose husbands inherited land seemed to enjoy even less say in the management and felt less control over the outcomes. As one woman divulged, "I have not even one tree of my own, and therefore nothing that I have control over to provide for my needs." She reasoned this could be remedied if her husband would "lead her to land” and she would then have enough money, but she said her “husband won’t lead, and prefers to hire labour on his land rather than enlisting [her help]”. She suggested that this situation had left her feeling powerless and without options or recourse.

Images of imagined futures constructed by indirect cocoa farmers - while primarily regarding the futures of their children - were framed in a negative light, which conveyed a sense of self-sacrifice, inevitability, and lack of alternatives. One indirect cocoa farmer explained: “I do not have much faith in the future of cocoa; it varies by year. In five years it could be good or dead. But there is not another option besides farming”. This attitude of resignation and without vision for future opportunities depicted by many indirect cocoa farmers suggests that the prospects for cultivating adaptive capacity are limited. It also suggests a relationship between lack of agency and lack of control over cocoa farming. This relationship can work in both directions; women with low perceptions of their empowerment and control over their lives might find themselves unable to negotiate access to cocoa or they may develop these subjective positions because they do not have access to cocoa. 
The inevitability of 'going without' during a bad year was another common theme. One indirect farmers’ lament was typical, “If crops don’t do well, you will be hungry, unless you have some money available to buy food.” This was indicative of the resignation to ultimately reducing quality of life or ability to provide adequately for their families, issues of greater relevance to those on the margins or experiencing poverty.

\section{Discussion and Conclusions}

\subsection{Exposure}

Climate change vulnerability in agricultural systems often focuses on the biophysical impacts on crop growth and yield. Climate change models project changes in temperatures and total amount, timing, and intensity of rainfall, and these variables often arose during discussions as factors in determining the success of a crop in any given year. When discussing the relevance of these variables to the exposure of farmers growing cocoa and other crops, both indirect and direct farmers focused primarily on rainfall, but diverged in how the rainfall issue was framed and in terms of the time-scales of relevance. The long-term outlook of direct farmers speaks to time-scales on which climate change operates and lends itself to the transformation potentially required for adaptation. Indirect cocoa farmers demonstrated a mind for seasonal and annual cycle more relevant to their food crop production, which may provide the flexibility needed to cope with variability and extreme weather events, but might not be sufficient for fundamental shifts in growing conditions.

The interview responses also indicated that it is not gender per se that forms weather and climate perceptions and exposure, but the types of livelihood strategies and land tenure that shapes their concerns and responses. In this instance, the extent of women's involvement in 
cocoa cultivation, rather than gender itself, suggests in what ways they might be exposed to climate change. This is important because exposure is not purely an outcome of biophysical processes, but is related to people's relationship to particular crops and parcels of land, and other variables may more fundamentally affect how sensitive women are to climate change and their capacities to adapt.

\subsection{Sensitivity}

From these interviews, livelihood diversification was the factor that corresponded most directly with sensitivity. While both indirect and direct cocoa farmers generated some income from food crops, the latter managed more elaborate portfolios of income and were more heavily involved in the off-farm economy, including preparing foods (e.g. watkye or rice balls) and 'odd jobs’ (e.g. midwifery or dishwashing in town). The combination of different agricultural strategies and diversity of livelihoods among women also has a profound influence on the sensitivity of women to climate change. There is clearly an interplay between land and income. For instance, food crops may have the advantage over cocoa in terms of flexibility of (shorter) cropping cycles, but cocoa production serves as an important precursor to obtaining funds or credit to invest in off-farm income sources, and makes branching into more ventures economically viable. This also relates to accumulating greater capital through involvement with the cocoa industry, which places many women in a better position to adapt to potential climate changes.

\subsection{Adaptive Capacity}

Finally, the previous sections pinpointed ways in which women in cocoa farming systems could be exposed to climate change and how access to alternative (non-cocoa) livelihoods 
characterize sensitivity among those farmers. But perceptions of power and agency also feed into vulnerability, affecting the capacity of women to respond and adapt to potential impediments. Disheartening circumstances or feelings of resignation and negativity may present a barrier to undertaking adaptive activities. The power of future-orientation emerged organically during the interviews for this study, corroborating the literature on adaptive capacity and empowerment in the face of climate change discussed earlier. While both indirect and direct cocoa farmers described hopes and future plans, the former cited few means or little confidence of achieving them. Conversely, direct cocoa farmers possessed a more solid grasp of how they might realize similar and often more ambitious goals.

There are other factors that can affect adaptive capacity, such as the ability to obtain information when the need arises, which likely vary among women and could be explored in future research. For instance, extension services and formal training - although already suboptimal in Ghana - often cater to commodity crop production and are less accessible for women (either due to their crops or the prominence of male extension agents) (Carr \& Thompson, 2014). Increasing accessibility to information could boost confidence and the perception of control over success, but also provide necessary tools to respond to novel climate conditions.

\subsection{Policy Implications}

There is a trade-off in analyses aiming to inform policy, between treating women as a homogeneous group in relation to men and describing the complex reality of relations between and within gender groups. Because of this variation, it is difficult to make a blanket statement that a certain "type" of woman is most vulnerable. But the importance of integrating concerns that reach beyond cocoa production and the biophysical response of the crop to climate change 
into policy is clear, and can help to avoid reinforcing the existing inequalities in the cocoa production system. The use of even a simple typology allows us to consider how underlying circumstances may predispose certain vulnerabilities, and also indicates how fundamental differences in capabilities can influence pathways out of poverty.

Variations in priorities and choices between direct and indirect farmers have implications for the types of interventions introduced. More traditional development and empowerment activities, such as improving educational opportunities and enabling access to finance for building businesses or acquiring land, may be most beneficial for indirect farmers. Whereas direct farmers may in fact benefit from the prescribed technical climate change adaptation tactics, such as providing information and making agricultural extension more amenable to women. Many of the policies and programmes in the climate and development sphere aim to alleviate poverty. Similarities and differences identified in this study also point to deeper social inequities underlying vulnerability. Simplification to homogeneous entities could compromise or preferentially favour specific pathways out of poverty over others.

There are also limits to what policy can achieve. The prominence of customary arrangements in dictating land tenure issues is a significant challenge for policy-makers interested in equitably addressing wellbeing in the cocoa sector. As most land is constitutionally vested in the stools, issues concerning land management are therefore distanced from policy control (Ubink \& Quan, 2008), minimizing the potential for statutory and policy reform to influence this critical component of vulnerability. That said, it is important to neither underestimate nor overestimate the role of policy and regulation in addressing vulnerability. Understanding social processes that dictate practices of inheritance, land distribution, and tenure security may ensure policy responses do not have perverse outcomes, such as undermining the 
power women possess to negotiate access to land via customary arrangements (Bromley, 2009;

Putzel, et al., 2015). This is important not only for customary tenure arrangements, but also on the other factors that have bearing on sensitivity, such as the ability to engage in multiple and off-farm livelihood activities.

While studies that highlight the adaptive and negotiable nature of land-labour-livelihood relationships under customary tenure arrangements are an extremely valuable corrective to simplistic and intervention-orientated analyses, Peters (2004) argues that attention should not be detracted away from the ongoing processes of exclusion and deepening social inequalities. In Ghana, women remain on the fringes of the cocoa sector: echoing findings elsewhere (Ackah \& Lay, 2009; Carr, 2008a), women in the case study site generally face greater difficulty acquiring their own land, and what they do control is smaller in size and of poorer quality than that of their male counterparts.

In recognition of the importance of cocoa in terms of climate impacts, mitigation, and adaptation, the country has begun to pursue a climate-smart agriculture approach to the sector aiming to, inter alia, increase incomes through improved agronomic practices and reduce carbon emissions by increasing shade trees on farms (Asare, 2014). As this and other climate related policies, such as the National Climate Change Adaptation Strategy, evolve and mature, it is essential that the dynamics of gender differentiated vulnerability is acknowledged in the cocoa sector and rural economy more broadly. If these efforts continue to focus on technical agronomic practices and fail to recognise the heterogeneity of women and their social, cultural and institutional contexts, then they risk continuing the trend of interventions in the field, which are strong on rhetoric but lack the transformative powers to realize goals of poverty alleviation and equality (Cornwall \& Rivas, 2015). 


\subsection{Conclusion}

In general, this study supports the idea that climate change aggravates existing social vulnerabilities (Demetriades \& Esplen, 2008). It is critical to recognize that while climate change is an enormous challenge, it builds on existing social and environmental issues (Mertz, et al. 2009). Interview respondents did not often explicitly implicate climate change in current and past vulnerabilities or threats in the future, but alluded to it as a contributing factor. This suggests elevating the importance of biophysical factors in vulnerability studies in agricultural contexts ignores the range of issues that shape both women's and men's exposure, sensitivity, and adaptive capacity. Importantly, it also overlooks the role of individuals’ perceptions and motivations in adapting to change and how risks compound the factors underlying individuals' vulnerabilities.

The emergence of climate-smart agricultural policies in Ghana and elsewhere (Asare, 2014; Jost et al., 2016) means it is increasingly important to understand the gendered dynamics of vulnerability, both to minimize the risk that homogenized discourses of gender exacerbates existing vulnerabilities and to maximally leverage policies that address inequalities. This research corroborated the notion that climate change policy in agricultural systems must move beyond purely agronomic and technical solutions to anticipated climate change impacts; women highlighted social and economic factors as pivotal in their abilities to address weather variability and extreme events, not merely the technical limitations of agricultural production.

Future research would benefit from further disaggregation to understand additional nuances and where specific interventions may assist particularly vulnerable subsets of the population. Further understanding the drivers of intra-household decision-making dynamics 
would also be valuable. Additional empirical studies incorporating this complexity into their design are important to continue building an evidence base and characterising specific vulnerable subsets of a population for policies and development programmes. Finally, while we used vulnerability as a lens through which to interrogate heterogeneity of gendered responses to climate change, this approach predisposes the analysis toward risks, hazards, and minimizing negatives. While employing a vulnerability framework serves to engage climate scholars and initiate a more nuanced discussion of gender issues in the climate discourse, to further explore the characteristics and drivers of empowerment, agency, and self-perceptions for building adaptive capacity to climate change, other frameworks may be better suited.

\section{Notes:}

1. Entitlements refer to access to different types of assets or capital, such as land, credit, and productive resources, and can include capabilities like literacy and education levels (Adger, 2006).

2. In this context agency includes the ability to conceptualize alternate futures, and to reflect on past and present circumstances and future manoeuvrability (Emirbayer \& Mische, 1998).

3. The term 'stool' in Ghana refers to the chiefly office (Sara, 2004). The Stools have considerable influence over cocoa land (i.e. it is very difficult to change cocoa to something else without permission).

4. Cocoa usually grows for 25-40 years, which corresponds to climatic (30 year) timescales.

\section{Acknowledgements}

The authors thank all the participants for their generosity in sharing their experiences and knowledge. They also thank all those who helped facilitate the research during fieldwork, especially Anne Adusei, Michael Adu-Sasu, Prosper Kapoti and Rebecca Asare. They also appreciate insightful discussions with other members of the ECOLIMITS research team and members of the ecosystem governance group at the Environmental Change Institute (ECI), University of Oxford. This work was funded through the Ecosystem Services for Poverty 
Alleviation (ESPA) programme (Project Code NE/K010379-1) funded by the Department for International Development (DFID), the Economic and Social Research Council (ESRC) and the Natural Environment Research Council (NERC) and the Understanding the Impacts of the Current El Niño Event programme (Project Code: NE/P00394X/1) funded by the DFID and NERC and a Santander Academic Travel Award.

\section{References}

Ackah, C., \& Lay, J. (2009). Gender Impacts of Agricultural Liberalisation: Evidence from Ghana. In de Hoyos, R. \& Bussolo, M. Gender Aspects of the Trade and Poverty Nexus: A Macro-Micro Approach (pp. 757-776). Washington, DC: The World Bank.

Adger, W. (2006). Vulnerability. Global Environmental Change, 16(3), 268-281. doi:10.1016/j.gloenvcha.2006.02.006

Adger, W. N., Dessai, S., Goulden, M., Hulme, M., Lorenzoni, I., Nelson, D. R., Naess, L.O., Wolf, J., \& Wreford, A. (2009). Are there social limits to adaptation to climate change? . Climate Change, 93(3-4), 335-354. doi: 10.1007/s10584-008-9520-z

Allman, J. (1996) Rounding up spinsters: gender chaos and unmarried women in colonial Asante. The Journal of African History 37: 195-214. doi:10.1017/S0021853700035192

Alston, M. (2014). Gender mainstreaming and climate change. Women's Studies International Forum, 47, 287-294. doi: 10.1016/j.wsif.2013.01.016

Amanor, K., \& Ubink, J. (2008). Contesting Land and Custom in Ghana. State, Chief and the Citizen. Leiden: Leiden University Press.

Antwi-Agyei, P., Fraser, E. D., Dougill, A. J., Stringer, L. C., \& Simelton, E. (2012). Mapping the vulnerability of crop production to drought in Ghana using rainfall, yield and socioeconomic data. Applied Geography, 32(2), 324-334. doi:10.1016/j.apgeog.2011.06.010

Arora-Jonsson, S. (2011). Virtue and vulnerability: Discourses on women, gender and climate change. Global Environmental Change, 21(2), 744-751. doi:10.1016/j.gloenvcha.2011.01.005

Asare, R. (2014). Understanding and Defining Climate-Smart Cocoa: Extension, Inputs, Yields, and Farming Practices. Climate-Smart Cocoa Working Group Report. Accra: Nature Conservation Research Centre/Forest Trends. 
Barrientos, S. (2013). Gender production networks : Sustaining cocoa-chocolate sourcing in Ghana and India. BWPI Working Paper no.186. Manchester: Brooks World Poverty Institute at University of Manchester.

Berry, P., Rounsevell, M. A., Harrison, P., \& Audsley, E. (2006). Assessing the vulnerability of agricultural land use and species to climate change and the role of policy in facilitating adaptation. Environmental Science \& Policy, 9(2), 189-204. doi:10.1016/j.envsci.2005.11.004

Berry, S. (1993). No condition is permanent: The social dynamics of agrarian change in subSaharan Africa. Madison: University of Wisconsin Press.

Berry, S. (2009). Building for the Future? Investment, Land Reform and the Contingencies of Ownership in Contemporary Ghana. World Development, 37(8), 1370-1378. doi:

10.1016/j.worlddev.2008.08.017

Beuchelt, T., \& Badstue, L. (2013). Gender, nutrition- and climate-smart food production: Opportunities and trade-offs. Food Security, 5, 709-721. doi:10.1007/s12571-013-0290-8

Bob, U., \& Babugura, A. (2014). Contextualising and conceptualising gender and climate change in Africa. Agenda, 28(3), 3-15. doi: 10.1080/10130950.2014.958907

Boserup, E. (1970). Woman’s Role in Economic Development. London: Earthscan.

Boyd, E. (2002). The Noel Kempff project in Bolivia: Gender, power, and decision-making in climate mitigation. Gender \& Development, 10(2), 70-77. doi:10.1080/13552070215905

Bradshaw, S., \& Linneker, B. (2014). Gender and Environmental Change in the Developing World. Working Paper. London: International Institute for Environment and Development (IIED).

Bromley, D. (2009). Formalising property relations in the developing world: The wrong prescription for the wrong malady. Land Use Policy, 26, 20-27.

doi:10.1016/j.landusepol.2008.02.003

Brown, K., \& Westaway, E. (2011). Agency, Capacity, and Resilience to Environmental Change: Lessons from Human Development, Well-Being, and Disasters. Annual Review of Environment and Resources, 36, 321-342. doi:10.1146/annurev-environ-052610-092905

Bunn, C., Läderach, P., Quaye, A., Sander, M., \& Lundy, M. (2016). Bittersweet Chocolate: The climate change impacts on cocoa production in Ghana. Cali: International Center for Tropical Agriculture (CIAT). Retrieved from http://arcg.is/1Sg047s 
Cannon, T. (2002). Gender and climate hazards in Bangladesh. Gender \& Development, 10(2), 45-50. doi: 10.1080/13552070215906

Carr, E. (2008a). Between structure and agency: Livelihoods and adaptation in Ghana's Central Region. Global Environmental Change, 18(4), 689-699. doi:10.1016/j.gloenvcha.2008.06.004

Carr, E. (2008b). Men’s Crops and Women’s Crops: The Importance of Gender to the Understanding of Agricultural and Development Outcomes in Ghana's Central Region. Global Environmental Change, 36(5), 900-915. doi:10.1016/j.worlddev.2007.05.009

Carr, E., \& Thompson, M. (2014). Gender and climate change adaptation in agrarian settings: Current thinking, new directions, and research frontiers. Geography Compass, 8(3), 182-197. doi:10.1111/gec3.12121

Challinor, A., Wheeler, T., Garforth, C., Craufurd, P., \& Kassam, A. (2007). Assessing the vulnerability of food crop systems in Africa to climate change . Climatic Change, 83(3), 381399. doi:10.1007/s10584-007-9249-0

Chaudhury, M., Kristjanson, P., Kyagazze, F., Naab, J., \& Neelormi, S. (2012). Participatory Gender-Sensitive Approaches for Addressing Key Climate Change-Related Research Issues: Evidence from Bangladesh, Ghana and Uganda. Working Paper no.19. Copenhagen: CGIAR CCAFS.

Coe, R., \& Stern, R. (2011). Assessing and addressing climate-induced risk in sub-Saharan rainfed agriculture: Lessons learned. Experimental Agriculture, 47(2), 395-410. doi:10.1017/S001447971100010X

Cornwall, A. ed. (2005). Readings in Gender in Africa. Bloomington: University of Indiana Press.

Cornwall, A., \& Rivas, A-M. (2015). From “gender equality and 'women’s empowerment” to global justice: reclaiming a transformative agenda for gender and development. Third World Quarterly, 36(2), 396-415. doi:10.1080/01436597.2015.1013341

Dankelman, I. (2002). Climate change: Learning from gender analysis and women's experiences of organising for sustainable development. Gender \& Development, 10(2), 21-29. doi:10.1080/13552070215899

Davis, B., Di Giuseppe, S., \& Zezza, A. (2014). Income Diversification Patterns in Rural SubSaharan Africa: Reassessing the Evidence. Policy Research Working Paper no.7108. Washington, DC: The World Bank. 
Demetriades, J., \& Esplen, E. (2008). The gender dimensions of poverty and climate change adaptation. IDS Bulletin, 39(4), 24-31. doi:10.1111/j.1759-5436.2008.tb00473.x

Denton, F. (2002). Climate change vulnerability, impacts, and adaptation: Why does gender matter? . Gender \& Development, 10(2), 10-20. doi:10.1080/13552070215903

Djoudi, H., Locatelli, B., Vaast, C., Asher, K., Brockhaus, M., \& Sijapati Basnett, B. (2016). Beyond dichotomies: Gender and intersecting inequalities in climate change studies. Ambio, 45(S3), 248-262. doi:10.1007/s13280-016-0825-2

Doss, C. (2002). Men's crops? Women's crops? The gender patterns of cropping in Ghana. World Development, 30(11), 1987-2000. doi: 10.1016/S0305-750X(02)00109-2

Duguma, B., Gockowski, J., \& Bakala, J. (2001). Smallholder Cacao (Theobroma cacao Linn.) cultivation in agroforestry systems of West and Central Africa: Challenges and opportunities. Agroforestry Systems, 51, 177-188. doi:10.1023/A:1010747224249

Duncan, B. (2010). Cocoa, marriage, labour and land in Ghana: some matrilineal and patrilineal perspectives. Africa, 80, 301-321. doi: 10.3366/afr.2010.0206

Eakin, H., \& Luers, A. (2006). Assessing the vulnerability of social-environmental systems. Review of Environment and Resources, 31, 365-394.

doi:10.1146/annurev.energy.30.050504.144352

Emirbayer, M., \& Mische, A. (1998). What Is Agency? American Journal of Sociology, 103(4), 962-1023. doi:10.1086/231294

Evans, R., Mariwah, S., \& Antwi, K. (2015). Struggles over family land? Tree crops, land and labour in Ghana’s Brong-Ahafo region. Geoforum, 67, 24-35.

doi:10.1016/j.geoforum.2015.10.006

FAO. (2011). Women in Agriculture: Closing the Gender Gap for Development. State of Food and Agriculture. Rome: Food and Agriculture Organization of the United Nations (FAO).

Füssel, H. (2007). Vulnerability: A generally applicable conceptual framework for climate change research. Global Environmental Change, 17(2), 155-167.

doi:10.1016/j.gloenvcha.2006.05.002

Hill, P. (1963). The Migrant Cocoa-Farmers of Southern Ghana: A Study in Rural Capitalism (Reprint). Oxford: James Currey Publishers.

Huyer, S. (2016). Closing the Gender Gap in Agriculture. Gender, Technology and Development, 20(2), 105-116. doi:10.1177/0971852416643872 
IPCC [Intergovernmental Panel on Climate Change]. (2014). Summary for Policymakers. In Field, C.B., Barros, V.R. , Dokken, D.J., Mach, K.J., Mastrandrea, M.D., Bilir, T.E., Chatterjee, M., Ebi, K.L., Estrada, Y.O., Genova, R.C., Girma, B., Kissel, E.S., Levy, A.N., MacCracken, S., Mastrandrea, P.R. \& White, L.L. Climate Change 2014: Impacts, Adaptation, and Vulnerability. Part A: Global and Sectoral Aspects. Contribution of Working Group II to the Fifth Assessment Report of the Intergovernmental Panel on Climate Change. (pp. 1-32). Cambridge/New York: Cambridge University Press.

Jackson, C. (2002). Disciplining Gender? World Development, 30(3), 497-509. doi:10.1016/S0305-750X(01)00113-9

Jost, C., Kyazze, F., Naab, J., Neelormi, S., Kinyangi, J., Zougmore, R., Aggarwal, P., Bhatta, G., Chaudhury, M., Tapio-Bistrom, M-L., Nelson, S., \& Kristjanson, P. (2016). Understanding gender dimensions of agriculture and climate change in smallholder farming communities. Climate and Development, 8, 133-144. doi:10.1080/17565529.2015.1050978

Kakota, T., Nyariki, D., Mkwambisi, D., \& Kogi-Makau, W. (2011). Gender vulnerability to climate variability and household food insecurity. Climate and Development, 3(4), 298-309. doi:10.1080/17565529.2011.627419

Kasanga, R., \& Kotey, N. (2001). Land management in Ghana: Building on tradition and modernity. London: International Institute for Environment and Development (IIED).

Kutsoati, E. \& Morck, R. (2014). Family ties, inheritance rights, and successful poverty alleviation: Evidence from Ghana, African Successes: Human Capital (Vol. 2). Chicago: University of Chicago Press.

Läderach, P., Martinez-Valle, A., Schroth, G., \& Castro, N. (2013). Predicting the future climatic suitability for cocoa farming of the world's leading producer countries, Ghana and Côte d'Ivoire. Climate Change, 119, 841-854. doi:10.1007/s10584-013-0774-8

Lambrecht, I. (2016). “As a Husband I will Love, Lead, and Provide.” Gender as a Social Construct in Shaping Women’s Access to Land in Ghana. Paper prepared for 2016 World Bank Conference on Land and Poverty. Washington, DC: World Bank.

Lambrou, Y. (2001). A Typology: Participatory Research and Gender Analysis in Natural Resource Management Research. Working Document no.15. Cali: CGIAR/Future Harvest.

Lambrou, Y., \& Piana, G. (2006). Gender: the missing component of the response to climate change. Rome: Food and Agriculture Organization of the United Nations (FAO).

MacGregor, S. (2010). 'Gender and climate change': from impacts to discourses. Journal of the Indian Ocean Region, 6(2), 223-238. doi:10.1080/19480881.2010.536669 
Masika, R. ed(2002). Gender, Development, and Climate Change. Eynsham: Oxfam GB, Information Press.

McOmber, C., Panikowski, A., McKune, S., Bartels, W.-L., \& Russo, S. (2013). Investigating Climate Information Services through a Gendered Lens. CCAFS Working Paper No. 42. Copenhagen: CGIAR Climate Change, Agriculture and Food Security Research Programme.

Meinzen-Dick, R., Kovarik, C., \& Quisumbing, A. (2014). Gender and sustainability. Annual Review of Environment and Resources, 39, 29-55. doi:10.1146/annurev-environ-101813-013240

Mertz, O., Mbow, C., Reenberg, A., \& Diouf, A. (2009). Farmers’ perceptions of climate change and agricultural adaptation strategies in rural Sahel. Environmental Management, 43(5), 804816. doi:10.1007/s00267-008-9197-0

MESTI. (2013). Ghana National Climate Change Policy. Accra: Ghana Ministry of Environment, Science, Technology and Innovation (MESTI).

Momsen, J. ed. (2010). Gender and Development (2nd ed.). Oxon: Routelage.

Moser, A. (2007). Gender and Indicators. Overview Report. Geneva: United Nations Development Programme.

Namubiru-Mwaura, E. (2014). Land Tenure and Gender: Approaches and Challenges for Strengthening Rural Women's Land Rights. Women's Voice, Agency, \& Participatory Research Series 2014 no.6. Washington, DC: World Bank.

Nelson, V. (2010). What role for agricultural research among smallholder farmers in Africa? CIAT Working Document no. 222. Kampala: CIAT.

Nelson, V., Meadows, K., Cannon, T., Morton, J., \& Martin, A. (2002). Uncertain predictions, invisible impacts, and the need to mainstream gender in climate change adaptations. Gender \& Development, 10(2), 51-59. doi:10.1080/13552070215911

Nyantakyi-frimpong, H., \& Bezner-kerr, R. (2015). The relative importance of climate change in the context of multiple stressors in semi-arid Ghana. Global Environmental Change, 32, 40-56. doi:10.1016/j.gloenvcha.2015.03.003

Olsson, L., Opondo, M., Tschakert, P., Agrawal, A., Eriksen, S. H., Ma, S., Perch, L.N., \& Zakieldeen, S. A. (2014). Chapter 13: Livelihoods and Poverty. In Field, C.B., Barros, V.R., Dokken, D.J., Mach, K.J., Mastrandrea, M.D., Bilir, T.E., Chatterjee, M., Ebi, K.L., Estrada, Y.O., Genova, R.C., Girma, B., Kissel, E.S., Levy, A.N., MacCracken, S., Mastrandrea, P.R. \& White, L.L. (eds.), Climate Change 2014: Impacts, Adaptation, and Vulnerability. Part B: Regional Aspects. Contribution of Working Group II to the Fifth Assessment Report of the 
Intergovernmental Panel on Climate Change (pp. 798-832). Cambridge/New York: Cambridge University Press.

Oppenheimer, M., Campos, M., Warren, R., Birkmann, J., Luber, G., O'Neill, B., \& Takahashi, K. (2014). Chapter 19: Emergent Risks and Key Vulnerabilities. In Field, C.B., Barros, V.R., Dokken, D.J., Mach, K.J., Mastrandrea, M.D., Bilir, T.E., Chatterjee, M., Ebi, K.L., Estrada, Y.O., Genova, R.C., Girma, B., Kissel, E.S., Levy, A.N., MacCracken, S., Mastrandrea, P.R. \& White, L.L. (eds.), Climate Change 2014: Impacts, Adaptation, and Vulnerability. Part B: Regional Aspects. Contribution of Working Group II to the Fifth Assessment Report of the Intergovernmental Panel on Climate Change (pp. 1039-1099). Cambridge/New York: Cambridge University Press.

Perez, C., Jones, E., Kristjanson, P., Cramer, L., Thornton, P., Förch, W., \& Barahona, C. (2015). How resilient are farming households and communities to a changing climate in Africa? A gender-based perspective . Global Environmental Change, 34, 95-107.

doi:10.1016/j.gloenvcha.2015.06.003

Peters, P. E. (2004). Inequality and social conflict over land in Africa. Journal of Agrarian Change, 4(3), 269-314. doi:10.1111/j.1471-0366.2004.00080.x

Preston, B., Yuen, E., \& Westaway, R. (2011). Putting vulnerability to climate change on the map: A review of approaches, benefits, and risks. Sustainability Science, 6(2), 177-202. doi:10.1007/s11625-011-0129-1

Putzel, L., Kelly, A., Cerutti, P., \& Artati, Y. (2015). Formalization as development in land and natural resource policy. Society \& Natural Resources, 28(5), 453-472.

doi:10.1080/08941920.2015.1014608

Quisumbing, A., Payongayong, E., Aidoo, J., \& Otsuka, K. (2001). Women’s Land Rights in the Transition to Individualized Ownership: Implications for Tree-Resource Management in Western Ghana. Development and Cultural Change, 50, 157-182. doi:10.1086/340011

Ravera, F., Iniesta-Arandia, I., Martín-López, B., Pascual, U., \& Bose, P. (2016). Gender perspectives in resilience, vulnerability and adaptation to global environmental change. Ambio, 45(S3), 235-247. doi:10.1007/s13280-016-0842-1

Resurrección, B. (2013). Persistent women and environment linkages in climate change and sustainable development agendas. Women's Studies International Forum, 40, 33-43.

doi:10.1016/j.wsif.2013.03.011

Reyes, R. (2002). Gendering responses to El Niño in rural Peru. Gender \& Development, 10(2), 60-69. doi:10.1080/13552070215907 
Ribot, J. (2010). Vulnerability Does Not Fall from the Sky: Toward Multiscale, Pro-Poor Climate Policy. In R. Mearns, \& A. Norton, eds. Social Dimensions of Climate Change: Equity and Vulnerability in a Warming World (pp. 47-75). Washington, DC: World Bank Publications.

Rodenberg, B. (2009). Climate Change Adaptation from a Gender Perspective: A cross-cutting analysis of development-policy instruments. DIE Research Report. Bonn: Deutches Institut Fur Entwickungspolitik.

Sara, B. (2004). Reinventing the Local? Privatization, Decentralization and the Politics of Resource Management: Examples from Africa. African Study Monographs, 25(2), 79-101. doi:10.14989/68230

Schipper, L., \& Langston, L. (2014). Gender equality and Climate Compatible Development: Drivers and challenges to people’s empowerment. London: Climate and Development Knowledge Network (CDKN).

Schroth, G., Läderach, P., Martinez-Valle, A., \& Bunn, C. (2016a). From site-level to regional adaptation planning for tropical commodities: cocoa in West Africa. Mitigation and Adaptation Strategies for Global Change, 1-25. doi:10.1007/s11027-016-9707-y

Schroth, G., Läderach, P., Martinez-valle, A., Bunn, C., \& Jassogne, L. (2016b). Vulnerability to climate change of cocoa in West Africa: Patterns, opportunities and limits to adaptation . Science of the Total Environment , 556, 231-241. doi:10.1016/j.scitotenv.2016.03.024

Seebens, H. (2010). Intra-household bargaining, gender roles in agriculture and how to promote welfare enhancing changes. ESA Working Paper no.11-10. Rome: Food and Agriculture Organization of the United Nations (FAO).

Simelton, E., Quinn, C.H., Batisani, N., Dougill, A.J., Dyer, J.C., Fraser, E.D.G., Mkwambisi, D., Sallu, S. \& Stringer, L.C. (2013). Is rainfall really changing? Farmers’ perceptions, meteorological data, and policy implications. Climate and Development, 5(2), 123-138. doi:10.1080/17565529.2012.751893

Siulemba, G. K., \& Moodley, V. (2014). Empowering women for gender equity: A gendered analysis of sustainable agricultural practices with changing climate in the Chankumba agricultural community. Agenda, 101(28.3), 135-146. doi:10.1080/10130950.2014.932126

Skinner, E. (2011). Gender and Climate Change Overview Report. Brighton: Institute of Development Studies.

Terry, G. (2009). No climate justice without gender justice: an overview of the issues. Gender \& Development, 17(1), 5-18. doi:10.1080/13552070802696839 
Thomas, D., Twyman, C., Osbahr, H., \& Hewitson, B. (2007). Adaptation to climate change and variability: Farmer responses to intra-seasonal precipitation trends in South Africa. Climate Change, 83(3), 301-322. doi:10.1007/s10584-006-9205-4

Thompson-Hall, M., Carr, E. R., \& Pascual, U. (2016). Enhancing and Expanding Intersectional Research for Climate Change Adaptation in Agrarian Settings. Ambio, 45(S3), 373-382. doi:10.1007/s13280-016-0827-0

Tschakert, P., \& Machado, M. (2012). Gender justice and rights in climate change adaptation: Opportunities and pitfalls. Ethics and Social Welfare, 6(3), 275-289.

doi:10.1080/17496535.2012.704929

Twomlow, S., Mugabe, F., Mwale, M., Delve, R., Nanja, D., Carberry, P., \& Howden, M. (2008). Building adaptive capacity to cope with increasing vulnerability due to climatic change in Africa: A new approach. Physics and Chemistry of the Earth, 33(8-13), 780-787. doi:10.1016/j.pce.2008.06.048

Ubink, J. M., \& Quan, J. F. (2008). How to combine tradition and modernity? Regulating customary land management in Ghana. Land Use Policy, 25(2), 198-213.

doi:10.1016/j.landusepol.2007.06.002

Vigneri, M., \& Holmes, R. (2009). When Being More Productive Still Doesn't Pay: Gender Inequality and Socio-Economic Constraints in Ghana's Cocoa Sector. Report from Workshop on Gaps, trends and current research in gender dimensions of agricultural and rural employment: differentiated pathways out of poverty. Rome: FAO-IFAD-ILO.

Westerhoff, L., \& Smit, B. (2009). The rains are disappointing us: Dynamic vulnerability and adaptation to multiple stressors in the Afram Plains, Ghana. Mitigation and Adaptation Strategies for Global Change, 14(4), 317-337. doi:10.1007/s11027-008-9166-1

Wise, R., Fazey, I., Stafford Smith, M., Park, S., Eakin, H., Archer Van Garderen, E., \& Campbell, B. (2014). Reconceptualising adaptation to climate change as part of pathways of change and response. Global Environmental Change, 28, 325-336.

doi:10.1016/j.gloenvcha.2013.12.002

Wong, S. (2009). Climate change and sustainable technology: re-linking poverty, gender, and governance. Gender \& Development, 17(1), 95-108. doi:10.1080/13552070802696953

Yin, R. (2003). Case study research: Design and methods (3rd ed.). Thousand Oaks: Sage Publishers. 
